\title{
Identifying the Best Innovation Behaviour Hotel in the Balaton Region of Hungary
}

\author{
Petra Gyurácz-Németh \\ University of Pannonia, Hungary \\ Nikolett Horn \\ Danubius Hotels Group, Hungary \\ Nóra Friedrich \\ University of Pannonia, Hungary
}

\section{Abstract}

The goal of the paper is to investigate the innovation behaviour of the hotels in the Balaton Region of Hungary and identify the best practice which is further analysed. The specific region has been chosen due to its popularity among Hungarian and foreign tourists, which is demonstrated by its second place in the number of guests and guest nights in the country. The research only considered those hotels which are members of the Hungarian Hotel and Restaurant Association and classified as three-, four- or five-star accommodation facilities. In the first stage the hotel general managers were asked to complete a questionnaire about the hotels' innovation behaviour. Then the best practice was identified and followed by an interview with the managers. There were 28 questionnaires completed, which is $52 \%$ of the hotels fitting the criteria. The results show that the definition of innovation is hard for the hotel general managers and hotels are focused on technological innovation, they do not concentrate on the environmental innovations and the most important barrier is the cost. The identified best practice hotel is Hotel Európa Fit**** superior, which emphasises human resource and organisational innovation and introduces socalled 'innovation by inspiring'.

Keywords: innovation behaviour, hotel, best practice, Balaton Region JEL classification: L83

\section{Introduction}

The economic and corporate importance of the innovation and the continuous improvement is obvious for all specialists. Today, in particular industries and specialist areas, such as the tourism industry, developing strategy to measure and examine this factor has a strategic importance. Tourism is one of the fastest growing industries today, which is significantly contributing to each country's GDP data and employment indicators. (Gyurácz-Németh et al., 2010)

The main aim of the paper is to investigate the significance of innovative thinking in the hotel industry in the Balaton Region of Hungary. Due to the large competition among hotels, it is more important to create new and special products to the consumer, which will satisfy their expected need and it will differentiate themselves from the competitors. The solution to stay competitive and sustainable is innovation.

As a result of the authors' research the best practice (the most innovative hotel) has been identified and examined further. The hotel is innovative and successful at the same time which seems to have a close relationship in the authors' opinion. 


\section{Literature review}

From the beginning, people have always tried to use newer and newer methods. The definition came up for the first time in Italy during the Renaissance in Europe, then again it became known by the Austrian economist Joseph Alois Schumpeter at the beginning of the $20^{\text {th }}$ century (Quadbeck-Seeger, 2003). Schumpeter (1934) said that innovation was a new way of doing things or a better / unique combination of production factors (Ottenbacher, 2008). As Schumpeter wrote, innovation creates new opportunities for valued added, it does not involve just the typical product/process innovation of manufacturing but also the market, organizational and resource input innovations too (Martínez-Ros et al., 2009).

According to the third edition they identified the definition of the innovation, which is the following: "An innovation is the implementation of a new or significantly improved product (good or service), or process, a new marketing method, or a new organizational method in business practices, workplace organization or external relations' (OECD, 2005:46). One of the most notable changes is that the 'technology' disappeared from the product and process innovation. It does not mean that the technology is not important anymore, it opens the definition to the lower intensity R\&D Company and to the service sector (Katona, 2006).

At first only production innovation had a big role in theory and practice, service innovation was not considered as an important issue until the beginning of this century (Djellal et al, 2013). Allegro et al. (2008) have found that the hotel industry's most innovative ideas come from those who have an outsider's perspective looking at the operation and they do not impede the existing paradigms. In hospitality innovation studies the role of employees (Chen, 2011, Nagy, 2014, Nieves \& SegarraCiprés, 2015) and the customer orientation (Grissemann et al, 2013) cannot be neglected. The advantages and disadvantages are summarised in Table 1.

Table 1

The advantages and disadvantages of hospitality innovation

\begin{tabular}{|c|c|}
\hline Advantages & Disadvantages \\
\hline $\begin{array}{l}\text { Competitiveness (Ottenbacher et al., } \\
\text { 2005) }\end{array}$ & $\begin{array}{l}\text { Failure rate: } 25-45 \% \text { (Cooper, 2008), 58\% } \\
\text { (Griffin, 1997) }\end{array}$ \\
\hline Business reputation (Ottenbacher, 2008) & Expensive (Ottenbacher, 2008) \\
\hline \multicolumn{2}{|l|}{ Loyalty (Ottenbacher, 2008) } \\
\hline \multicolumn{2}{|l|}{ Growing sales (Nicolau et al., 2013) } \\
\hline $\begin{array}{l}\text { Higher stock exchange returns (Nicolau } \\
\text { et al., 2013) }\end{array}$ & \\
\hline
\end{tabular}

Source: authors' own compilation

The most important advantage of innovation is competitiveness which is derived from the continuous improvement of the services of the hotel (Ottenbacher et al., 2005). The intangible factors are business reputation and guest loyalty. Innovation has a correlation with the sales activity and stock exchange return of the hotels as well (Nicolau et al., 2013). The most dangerous disadvantage of innovation is that most of the innovations cannot reach the original goals which make improvements very risky (Griffin, 1997). Even if the innovation is successful, it is still very expensive (Ottenbacher, 2008).

Innovation can be classified in different ways. The following groupings were used in the research. 
Table 2

Different innovation classifications

\begin{tabular}{ll}
\hline Author & Innovation classification \\
\hline $\begin{array}{l}\text { Dewar et al.(1986), and } \\
\text { Ettlie (1984) }\end{array}$ & Radical, incremental \\
Lovelock et al. (2007) & $\begin{array}{l}\text { Major innovations, New business, A new service has } \\
\text { been served market, Service line extension, Service } \\
\text { development, Style changes }\end{array}$ \\
Tseng et al.(2008) & $\begin{array}{l}\text { Technological, Organisational, Human capital } \\
\text { innovation }\end{array}$ \\
$\begin{array}{l}\text { Gyurácz-Németh et al. Sources of innovation: Management, Not-management } \\
(2010)\end{array}$
\end{tabular}

Source: authors' own compilation

From the classification criteria in Table 2, Tseng et al.'s (2008) groups have been further analysed and applied in this case study.

\section{Methodology}

Qualitative and quantitative research methods have been used in this current survey. In this paper the quantitative methods are not going to be detailed, but it is important to mention that 28 hotels filled out the questionnaire which is $52 \%$ of the population. Only three-, four and five-star hotels were asked. The best practice was identified(based on the number of innovations, type, nature, investment, frequency) and the qualitative research allowed the authors to find out more information about innovation in case of the hotel. An interview was made with the general Manager of the hotel which made it able for the authors to ask difficult questions as well to really map the innovation 'secret' of the hotels.

\section{Results}

After analysing the quantitative research results, it became possible to identify the best practice from the hotels of the Balaton Region of Hungary, which is the Hotel Európa Fit***superior in the town of Hévíz. The choice was supported by the fact that the exact questionnaire (for quantitative research) has been asked personally and a longer interview has been made with the general manager of the hotel. The follow-up interview was conducted on the $25^{\text {th }}$ March in 2014. The aim of this interview was to get more detailed information about the organisational aspects of innovation in the best practice.

\section{About the hotel}

One of the most famous thermal baths in Europe can be found in Hévíz. This medicinal lake - unique throughout the world - is found amongst exquisite green surroundings. The Hotel Európa Fit****superior is a four star spa and wellness hotel located in the heart of a peaceful oasis, the staff and the variety of wellness-, and beauty services give the guests the feeling of being really cared for. The hotel offers 234 rooms - for different needs - each with balcony/terrace and equipped with modern and necessary equipment. The whole hotel is air-conditioned.

The following services are provided by the hotel:

- Medical wellness cures in a new environment, modern and pampering treatments, alternative medicine and dental services as well 
- Massages: refreshing, sport and traditional Far Eastern massages

- Treatments: electrotherapy, pelotherapy, hydrotherapy, oxygen therapy, magnet therapy, inhalation, special packs, remedial gymnastic, medical examination, counselling, general medical check-up, dietetic consultation, California bath, Hévíz mud-bath, Humino treatment, cryosauna

- Pools: over $700 \mathrm{~m}^{2}$ water surface, wellness pool, medicinal pool, experience bath, indoor and outdoor swimming pools, Acapulco pool for families, whirlpool and Kneipp pool

- Saunas: Finnish saunas, infrasauna, steam bath, herbarium and a frigidarium ReneSanarium

- Vitalium Beauty: relaxing atmosphere, face and body treatments, massages, thalassotherapy, mesotherapy, cosmetics, hair styling, manicure, pedicure, cosmetician's consultation, solarium

(http://www.europafit.hu/en/hotel/introduction 01/07/2015)

\section{Innovation}

Although several hotel general managers misinterpret innovation, for example they identify innovation as maintenance or hygienic renovations, the best practice (Hotel Europa Fit) concentrates on service development in the definition. The general manager uses visions in the service development tasks, which are discussed in the annual meetings from a strategic and financial perspective.

The organisation has been created according to the need to innovate, the operational issues for example assuring the ADR (average daily rate) and other kind of performance indicators have only secondary importance. Developments start by a kick-off meeting at the beginning of the year. In the hotel they realised that there should be a deadline for every task, as this will make sure that effort is made and a new or altered service is created. So after the kick-off meeting there is a discussion every month, where they check the progress of the innovations and other relevant issues. The most important thing is to separate the meetings and tasks considering operational/everyday issues and strategic/long-term issues containing innovation.

For example, at one meeting the most essential topic of the meeting was to deal with the TripAdvisor comments. This discussion happened in a very different environment - in the Oxygen Adrenalin Park - where team building exercises helped the process. The event was successful and a new strategy was made to assure guest satisfaction. They will encourage their guests to write as many comments to the site as possible to create the real image of the hotel and to make sure that new guests will see the real picture instead of the negative comments which are more likely to be on TripAdvisor. These team building programs have been organised in the hotel since 2009.

This year the hotel has initiated an energy optimisation program, which aim is to reduce the energy costs of the hotel or make the system more efficient. This is one of the reasons why it is essential for the hotel that the staff have the chance to "come forward' and visit the general manager to suggest new, innovative ideas.

\section{Service development teams}

In the hotel they use service development teams as they see this task to be the most essential according to the general manager. The teams contain employees from every department. The aim is to involve the opinion leaders who are willing to share their thoughts with the group. There are currently ten people in the team, who are not necessarily department leaders but those who are creative and willing to raise the service quality of the hotel with new ideas. The middle managers of the different 
departments need to understand, as well, that their employees can have very good ideas and sometimes they are going to be the 'project managers'. This team has meetings at least once in three months without the general manager to make sure that they do not keep their ideas to themselves, but dare to criticise and create new things.

\section{Innovation by inspiration}

Hotel Európa fit****superior has a very good philosophy, which is called innovation by inspiration where the two concepts are connected. Setting aside any notion of the autocratic management style, the general manager was able to motivate the managers to share their opinions and suggestions. The colleagues have to prove the relevance and value of their ideas and describe the processes of implementation. There is always a discussion among the managers to find the strengths and weaknesses of the recommended solutions. The final decision is made by the general manager since he is the one taking the responsibility for all actions in the hotel. The general manager believes that only that strategy can work where everybody can share their opinion and he is only the 'first among equals'.

Although the other stakeholders like the owners cannot be forgotten. They need to support the new ideas since they are the ones who risk their financial resources to accomplish the dreams of the managers and the staff.

The general manager also mentioned that the revolutionary thoughts and innovations do not only come from inside the company but from other sources for example journals, magazines and from other secondary sources. These suggestions can be applied in practice, for example the general manager read a paper about Marriott hotels and it gave the idea to rethink the minibar service of the hotel which saved a lot of costs. However according to his opinion, it is not a good idea to copy the innovation of other hotels since the circumstances, the target groups and even the financial opportunities can be quite different.

\section{Innovation success and failure}

It is very hard to measure the success of innovation and it can be quite subjective as well. The aim of the innovation activity in case of Hotel Európa Fit is to make the hotel more competitive and reach the proper operational performance.

This thinking will lead to guest satisfaction as well which is an essential indicator in case of a hotel. Although customer satisfaction is a crucial input, employee satisfaction cannot be forgotten. An exhausted, overwhelmed, underpaid staff cannot satisfy the guests and improve or maintain the image of the hotel. This will not lead to competitiveness or better image. There were bad examples in Hévíz as well according to the general managers, so most of the staff of that hotel now works for Hotel Európa Fit.

\section{Discussion}

The information collected through the interview was able to provide the necessary data which was needed to describe the characteristics of the best practice hotel in the Balaton Region of Hungary.

The case study contains the most important information about the innovation activity of the hotel. As a summary it has to be noted that the general manager of the Hotel Európa Fit is very competent in the topics of hotel and innovation management as well.

The most mentioned innovation is organisational (service development teams, brainstorming meetings) and human resource innovations (training), although he 
emphasized the role of technological innovations as well. In the authors' opinion the organisational innovations are the basis of all developments in the hotel.

According to the general manager, there is no good example in Hungary, which they could learn from and Hungarian hotels are not open for new innovations. Although there is a contradiction here, because their competitor - according to the authors - Hotel Carbona**** introduced a new service (cryptotherapy) at the same time as Hotel Európa Fit****superior did, so other hotels can be innovative as well.

Innovation can come from different sources, which are known to the general manager, including cooperation among others. That is the reason why he set up a meeting with other hotel general managers in Hévíz every month. In these discussions the participants discuss the development opportunities and the problems as well. The extension of this cooperation is suggested.

One of the most important messages is the involvement and empowerment of employees to take part in the innovation processes of the hotel. To encourage the staff the general manager needs to be understanding, open and inspiring. Two-way communication is necessary with the guests, managers and the employees.

\section{Conclusion}

Today's competitive environment forces companies to keep up with the constant changes. The key to satisfy guests, owners and employees and produce the right performance indicators is to renew all the time. The current research investigated how innovative the hotels are in the Balaton Region of Hungary. This paper only concentrates on the qualitative part of the research to describe the best practice found in the Hotel Európa fit****superior.

The most important type of innovation used in the hotel is organisational innovation, which is the basis of all the others applied in the example hotel. The key to success lies with the philosophy of the general manager called 'innovation by inspiration'. The door is always open for new and creative ideas.

The other significant innovative practice is to get innovation ideas from different sources. The general manager uses practice, literature and he introduced a way of cooperation with other hotels in the same destination.

The authors believe that innovation has to be a strategic decision instead of an operative one and can come from different levels of the organisation or outside of the hotel. The most important thing for general managers is to be always open and try to find opportunities all the time and not to be satisfied with the current situation of the hotel as was mentioned by the best practice hotel's general manager.

Although there was much relevant information gathered during the interview, there are some limitations which have to be mentioned. The research only concentrated on the Balaton Region not the whole country. There was no foreign comparison and only the three-, four- and five-star hotels were analysed.

Further research is going to consider other parts of the country and try to involve more and more hotels to have a representative sample. A foreign best practice is going to be introduced as well and compared to the Hungarian best innovative hotel.

\section{References}

1. Allegro, S., de Graaf, R. (2008),"Innovation and strategy implementation: the key challenge in today's competitive atmosphere", Olsen, M., Zhao, J., Handbook of hospitality strategic management, Butterworth Henemann, Oxford, pp. 407-424.

2. Chen, W.J. (2011),"Innovation in hotel services: Culture and personality" ,International Journal of Hospitality Management, Vol. 30 No. 1, 64-72. 
3. Cooper, R.G. (2008), "Perspective: The stage-gate idea-to-launch process - update, What's new and nexgen systems", Journal of Product Innovation Management, Vol. 25 No. 3, 213-232.

4. Dewar R.D., Dutton J.E., (1986), "The adoption of radical and incremental innovations: anempirical analysis", Management Science, Vol. 32 No. 11, pp. 1422-1433.

5. Djellal, F., Gallouj, F., Miles, I. (2013), "Two decades of research on innovation in services: Which place for public services?", Structural Change and Economic Dynamics, Vol. 27, pp. 98-117.

6. Ettlie J.E., Bridges W.P., O'Keefe R.D. (1984), "Organization strategy and structuraldifferences for radical vs. incremental innovation", Management Science, Vol. 30 No. 6, pp. 682-695. fókuszban a szállodaipar és a közlekedés" (The sources of innovation in tourism, hotel and transport sector is in the focus), Innováció, Csath, M., Versenyképesség, KKV-K I.,Nemzetközi Konferencia Monográfia, Kodolányi János Főiskola, Budapest.

7. Griffin, A. (1997), "PDMA research on new product development practice: updating trends and benchmarking best practises", Journal of Product Innovation Management, Vol. 14 No 6, 429-458.

8. Grissemann, U., Plank, A., Brunner-Sperdin, A. (2013),"Enhancing business performance of hotels: The role of innovation and customer orientation", International Journal of Hospitality Management, Vol. 33, 347-356

9. Gyurácz-Németh, P., Raffay, Á., Kovács, Z. (2010), "Az innováció forrásai a turizmusbanKatona, J. (2006), "Oslo kézikönyv harmadik kiadásának kiértékelése" [Evaluating the 3rd edition of the Oslo manual], available at: http://www.innovacio.hu/download/az_innovacio_ertelmezese_2006_09_27.pdf (accessed April 26 th 2015).

10. Lovelock, C., Wirtz, J. (2007), "Services Marketing, People, Technology, Strategy", 6th Edition, Pearson Education International, USA

11. Martínez-Ros, E., Orfila-Sintes, F. (2009), "Innovation activity in the hotel industry", Technovation, Vol.29 No. 9, pp. 632-641.

12. Nagy, A. (2014),"The orientation towards innovation of spa hotel management: the case of Romanian spa industry", Procedia - Social and Behavioral Sciences, Vol. 124, pp. 425431.

13. Nicolau, J.L., Santa-María, M.J. (2013), "The effect of innovation on hotel market value", International Journal of Hospitality Management, Vol. 32, pp. 71-79.

14. Nieves, J., Segarra-Cipés, M. (2015),"Management innovation in the hotel industry", Tourism Management, Vol. 46, pp. 51-58.

15. OECD (2005), "Oslo manual", $3^{\text {rd }}$ edition p. 30, 16-17., available at: www.innovacio.hu/download./az innovacio_ertelmezese_2006_09_27.pdf laccessed: April 27 2015 )

16. Ottenbacher, M. (2008),"Innovation management", Jones, P., Handbook of hospitality operations and IT, Elsevier Ltd., Oxford, pp. 340-366.

17. Ottenbacher, M., Gnoth, J. (2005), "How to develop successful hospitality innovation", Cornell Hotel and Restaurant Administration Quarterly, Vol. 46 No. 2, pp. 205-222.

18. Quadbeck-Seeger, H. J. (2003), "Csak a változás állandó. Idézetek és gondolatok az innovatívvezetők számára" (Only the change is stable. Quotes and thoughts for innovative managers), KJK-Kerszöv Jogi és Üzleti Kiadó Kft., Budapest.

19. Schumpeter, J.A. (1934), "The Theory of Economic Development", Harvard University Press, Cambridge, Mass.

20. Tseng C., Kuo H., Chou S. (2008), "Configuration of innovation and performance in theservice industry: evidence from the Taiwanese hotel Industry", The Service Industries Journal, Vol. 28 No. 7, pp. 1015-1028.

21. Hotel Európa Febsite, available at: http://www.europafit.hu/en/hotel/introduction 01/07/2015 (accessed April 26 th 2015).

22. Interview with László Könnyid, General manager of the Hotel Európa Fit****superior (March 25th 2014) 


\section{About the authors}

Petra Gyurácz-Németh, PhD is a senior lecturer at the Department of Tourism, Faculty of Business and Economics, University of Pannonia, Veszprém, Hungary. Her main research field is hotel quality and innovation concentrating on the standardisation and customisation of hotel processes. She teaches subjects in connection with hotel operations and management, as well as service quality. Petra gained practical experience when she was working in an international chain hotel in many departments, in a tour operator as an incoming agent and in a touriform office. Author can be contacted at nemeth@turizmus.uni-pannon.hu

Nikolett Horn is a former student at the University of Pannonia, Veszprém, Hungary. She started her undergraduate studies in tourism and hospitality in 2008 and right after that continued by tourism management master. Her research topic is hotel project management and innovation. She took part in student scientific competitions where she placed first twice and second once. In the national student scientific competition she placed third and got a special award in the previous event. She has been working for the hotel chain Danubius Hotels Group as a sales representative. Author can be contacted at hornniki@gmail.com

Nóra Friedrich is a former BA and MA student at the University of Pannonia, Veszprém, Hungary. Her research topic is hotel innovation: types, behaviour and success. She assisted some projects at the Department of Tourism and made several presentations for students in different topics. She took part in more student scientific competitions where she placed first twice and second once. In the national student scientific competition she placed third, second and third again with different pieces of research. Author can be contacted at fnori89@gmail.com 